\section{Ageing of Nerve Cells}

THe human brain contains hundreds of different types of nerve cells of varying structures. Each type is found in a circumscribed area, and forms, either on its own or together with a few other type of nerve cells, a grey centre or 'griseum'. As a result of the aggregation of the representatives of one cell type in a circumscribed region, the task of following the life-history of that particular cell type under
normal or pathogenic conditions becomes possible, or at least easier. ormal or pathogenic conditions becomes possible, or at least easier.
Most representatives of a cell-type mature, age or 'fall ill' simultaneously.

To a large extent, the time course and morphological features of ageing are different in each cell type. The ageing process or 'involution' of a cell is different from any other regressive process or 'degeneration' it may undergo, but degenerative processes may, of course, occur in combination with an involution.

The time of onset of ageing of different cell types is sufficiently determined to permit an average order or 'pattern' of ageing to be established. Thus the cells of the inferior olivary body age particularly early, those of the pons much later, the vital cells of the medulla oblongata very late.

The ageing process always leads to the death of the cell. If it occurs at an average (normal) time, it causes partial death of the brain through normal death of the cell type in question. If a person lives sufficiently long, partial death of the vital cells of the medulla causes his or her death as a normal phenomenon. This form of death is a
rare occurrence, because death through disease usually terminates the individual life at an earlier stage.

Mutations may delay or accelerate ageing in general. Frequently, however, their effect is restricted to certain cell types. If their effect is thus strong but circumscribed, it produces the so-called 'systemic involutions'. An example is the premature ageing, in paralysis agitans, of the nerve cells which contain melanin.

External factors may also affect the process of ageing. Arteriosclerosis, temporary hypoxæmia, poisoning (for example, by carbon monoxide) and infections (as in the case of Parkinsonism after encephalitis) may lead to premature ageing.

Lastly, the degree of activity of a particular cell type has a great effect on its ageing process. Destruction of nerve cells which normally stimulate other ganglion cells causes premature ageing of those cells which now receive fewer impulses. After the destruction of the cells of the corpus striatum, for example, there occurs a trans-neura] of the corpus striatum, for example, there occurs a trans-neura.
involution of the cells of the nucleus pallidus. On the other hand, involution of the cells of the nucleus pallidus. On the other hand, involution is delayed not only by normal but also by such excessive
activity of nerve cells as results in their hypertrophy. Accordingly, in particularly active individuals the ageing of certain ganglion cells is delayed.

is delayed. In different cell types, the ageing process produces different counter-
reactions. One such reaction is the increase in Nissl granules ('hypertireactions. One such reaction is the increase in Nissl granules ('hyperti-
grosis'), produced by an augmented activity of the nucleolus; another grosis'), produced by an augmented activity of the nucleolus; another been wrongly interpreted as a degeneration. Another is probably the been wrongly interpreted as a degeneration. Another is probably the vacuolization regularly observed during the involution of ganglion
cells containing melanin. These counter-measures are particularly cells containing melanin. These

conspicuous in active individuals.
It is well known that cell division rejuvenates the cell while it interrupts its work. Divisith of a nerve cell would, accordingly, temporarily suppress its readiness for action. More important still, division would, by distributing the cell processes between two cells, destroy the adaptation to the reception and emission of impulses produced by the cell's previous activity. Lastly, the correct halving of long processes, for example, of the axons of giant pyramidal cells which are about $1 \mathrm{~m}$. long and about $10 \mu$ thick, appears to be mechanically impossible. It is, for example, known that the flbroblasts of Triton which bear processes withdraw these before undergoing cell division. From a functional point of view, however, the long processes of certain nerve cells are essential for an increased integration. We may, therefore, interpret the cessation of nerve cell division during embryonic development as a biological progress useful for selection but achieved at the price of individual death. In the breeding of particularly active individuals lies a

Institut für Hirnforschung,

CECILE VOGT July 25.

\section{Pattern of Recovery in Protein Deficiency}

REPEATED plasma volume determinations on liberated Indian prisoners-of-war suffering from extreme protein insufficiency have aturn to normal in a definite sequence. These patients had, at the time they were first studied, a normochromic macrocytic anæmia, a reduced body weight, a reduced serum total protein concentration, confined albumin/globulin ratio, a slightly reduced plasma volume and, because albumin/globulin ratio, a slightly reduced plasma volume and, because was, therefore, a great reduction in the total circulating hæmoglobin was, therefore, a great reduction in the total circulating hæmoglobin and total circulating plasma protein. When the patients were given to normal according to a definite pattern. For the sake of ease of to normal according to a definite pattern. For the sake of ease of description, the recovery process has been divided into three stages.
These are purely arbitrary, and may show considerable variation in their time relation.

Stage 1 (0-4 weeks) is characterized by the rapid rise in plasma volume to normal. During this period the body-weight falls as the œdema disappears and may then slowly rise. The blood-volume rises steadily, but at such a rate that, although the hæmoglobin concentration and the hæmatocrit falls, the total circulating hæmoglobin increases. Although the hæmoglobin concentration falls, the red blood corpuscle concentration usually increases, since at this time the patient's blood is rapidly becoming less macrocytic. The total circulating plasma protein increases, but, because of the rapid rise in plasma volume, the plasma protein concentration changes but little. More
albumin is formed than globulin, so the albumin/globulin ratio increases slightly.

Stage $2(2-12$ weeks $)$ is characterized by the rapid rise of both the Stage $2(2-12$ weeks) is characterized by the rapid rise of both the blood volume and the total circulating plasma protein to normal. The plasma volume, which had attained normal values in Stage 1 , increases rapidly to values well above normal. There is also a rapid increase in body-weight and in total circulating hæmoglobin, because
both the hæmoglobin concentration, which fell in Stage 1, and the both the hæmoglobin concentration, which fell in Stage 1, and the increases more rapidly than the globulin, but the latter does, however, reach figures in excess of normal. The albumin/globulin ratio continues to increase.

Stage 3 (8-16 weeks) is marked by the transition from Stage 2 to normal values. The plasma-volume, which rose to above normal in Stage 2, returns to normal, and the blood-volume, which had reached normal in Stage 2, remains there. The body-weight, the hæmoglobin concentration and the total circulating hæmoglobin all steadily rise. There is also a steady rise in the plasma protein concentration, but because of the fall in plasma-volume, the total circulating plasma protein remains the same. There is, however, still a rise in the tota circulating albumin, which is balanced by a corresponding fall in the total circulating globulin. This is reflected in the continued increase of the albumin/globulin ratio.

STAGES OF RECOVERY IN PROTEIN DEFICIENCY

\begin{tabular}{|c|c|c|c|}
\hline & $\begin{array}{c}\text { Stage } 1 \\
(0-4 \text { weeks })\end{array}$ & $\begin{array}{c}\text { Stage 2 } \\
(2-12 \text { weeks })\end{array}$ & $\begin{array}{c}\text { Stage 3 } \\
(8-16 \text { weeks) }\end{array}$ \\
\hline Body-weight. & Decreases. & $\begin{array}{c}\text { Increases } \\
\text { rapidly. }\end{array}$ & $\begin{array}{l}\text { Increases to } \\
\text { normal. }\end{array}$ \\
\hline $\begin{array}{l}\text { Plasma } \\
\text { volume. }\end{array}$ & $\begin{array}{l}\text { Increases rap- } \\
\text { idly to normaI. }\end{array}$ & $\begin{array}{l}\text { Increases rap- } \\
\text { idly to above } \\
\text { normal. }\end{array}$ & $\begin{array}{l}\text { Decreases to } \\
\text { normal. }\end{array}$ \\
\hline Blood volume. & Increases. & Increases to & No change. \\
\hline $\begin{array}{c}\text { Hb. conc. and } \\
\text { Hæmatocrit. }\end{array}$ & $\begin{array}{l}\text { Decreases or } \\
\text { no change. }\end{array}$ & Increases. & $\begin{array}{l}\text { Increases to } \\
\text { normal. }\end{array}$ \\
\hline $\begin{array}{l}\text { Total circul- } \\
\text { ating Hb. }\end{array}$ & Increases. & $\begin{array}{l}\text { Increases } \\
\text { rapidly. }\end{array}$ & $\begin{array}{l}\text { Increases to } \\
\text { normal. }\end{array}$ \\
\hline R.B.C. conc. & $\begin{array}{l}\text { Increases } \\
\text { slightly or no } \\
\text { change. }\end{array}$ & Increases. & $\begin{array}{l}\text { Increases to } \\
\text { normal. }\end{array}$ \\
\hline $\begin{array}{l}\text { Plasma pro- } \\
\text { tein concen- } \\
\text { tration. }\end{array}$ & $\begin{array}{l}\text { No change or } \\
\text { increases } \\
\text { slightly. }\end{array}$ & $\begin{array}{l}\text { Increases } \\
\text { rapidly. }\end{array}$ & $\begin{array}{l}\text { Increases } \\
\text { slightly to } \\
\text { normal. }\end{array}$ \\
\hline $\begin{array}{l}\text { Total circul- } \\
\text { ating plasma } \\
\text { protein. }\end{array}$ & Increases. & $\begin{array}{l}\text { Increases very } \\
\text { rapidly to } \\
\text { normal. }\end{array}$ & No change. \\
\hline $\begin{array}{l}\text { Total circul- } \\
\text { ating albu- } \\
\text { min. }\end{array}$ & Increases. & $\begin{array}{l}\text { Increases } \\
\text { rapidly. }\end{array}$ & $\begin{array}{c}\text { Increases to } \\
\text { normal. }\end{array}$ \\
\hline $\begin{array}{c}\text { Total circulat- } \\
\text { ing globulin. }\end{array}$ & $\begin{array}{l}\text { Increases } \\
\text { slightly to } \\
\text { normal. }\end{array}$ & $\begin{array}{l}\text { Increases to } \\
\text { above } \\
\text { normal. }\end{array}$ & $\begin{array}{l}\text { Decreases to } \\
\text { normal. }\end{array}$ \\
\hline $\begin{array}{l}\text { Albumin/glob- } \\
\text { ulin ratio. }\end{array}$ & $\begin{array}{l}\text { Increases } \\
\text { slightly. }\end{array}$ & Increases. & $\begin{array}{l}\text { Increases to } \\
\text { normal. }\end{array}$ \\
\hline
\end{tabular}

The above description, which is of necessity an over-simplification, is summarized in the accompanying table. Full details of these findings will be published elsewhere.

I am grateful to the Director of Medical Services, India, for permission to publish this report.

\section{Marasmus Research Team*, India Command.}

* Other members of the team, Lieut.-Col. J. H. Walters, I.M.S., and Major H. Lehmann, R.A.M.C.

\section{Utilization of Phenols and Related Compounds by Achromobacter}

THE splitting of aromatic rings by certain bacteria, particularly soil bacteria, was observed many years ago, and has been described by various authors ${ }^{1}$. Some of these micro-organisms were growing on media in which the only source of carbon was a romatic hydrocarbons or phenols ${ }^{2}$. Hitherto the mechanism of the process, as well as the range of compounds decomposed by those bacteria described, have not been investigated carefully.

In our experiments we isolated from heavily manured soil certain strains of bacteria - Achromobacter type- the biological character of which did not differ from that of the standard types of these bacteria. All these strains were grown on inorganic phosphate medium (a modification of Grey and Thornton medium ${ }^{3}$ ) and phenol was added as the sole source of carbon. One of these strains was selected for more detailed experimentation.

Bacteria of this strain grew readily when $0 \cdot 1$ per cent phenol was used as the source of carbon, while the addition of 0.15 per cent prevented growth, but did not kill the bacteria until cultures were ten days old. The $0 \cdot 2$ per cent phenol exerted marked bacteriocidal activity in 48 hours. The aliphatic compounds (glucose, acetate, citrate) were a more convenient source of carbon for the selected strain and produced growth two to four times as abundant as the medium containing phenol. The curve representing the rate of growth on phenol was always reproducible, if the same conditions were main- 